ISSN 0258-7122

Bangladesh J. Agril. Res. 34(1) : 165-168, March $2009 \quad$ Short Communication

\title{
EFFICACY OF DIFFERENT BAGGING MATERIALS FOR THE CONTROL OF MANGO FRUIT FLY
}

\author{
D. SARKER ${ }^{1}$, M. M. RAHMAN ${ }^{2}$ AND J. C. BARMAN ${ }^{2}$
}

Key Words: Bagging materials, control, mango fruit fly.

Different bagging materials (black polybag, transparent polybag, brown paper bag) were evaluated for the control of mango fruit fly attacking Langra and Khirshapat variety at the mango orchards of Mango Research Station and Lac Research Station, Chapai Nawabganj during May to June 2001 and 2003. Though all bagging materials gave $100 \%$ protection of mango fruits against the fruit fly infestation, bagging of fruits with brown paper bag was found to be the best in protecting mango fruits and provides almost similar \% total soluble solid (TSS) and physical fruit quality (expressed by \% black spots) in bagged fruits when compared with the un-bagged healthy fruits of the control treatment.

Mango (Mangifera indica L.) is one of the most popular and important fruit crop among all fruits in Bangladesh covering the largest area (50,000 ha.) and the total production (1,90,000 tons) being in the 3rd position after banana and jackfruit (Bhuyan et al., 2003). It provides a lot of energy with as much as 74 Kcal per 100g edible portion (Hossain, 1989). Both unripe and ripe mangoes are good source of vitamin C. Besides many other factors, insect pests play a vital role for the low yield and poor quality of mango fruits. The mango fruit fly, Bactrocera dorsalis (Hendel) (Tephritidae : Diptera) is a major pest of the mango fruits of Khirshapat, Langra, and Fazli varieties of mango (Karim, 1989). A huge quantity of mango fruits may be lost due to the fruit fly infestation every year. Bagging of mango fruits with paper or polythene bags may prevent the contact of female flies with the fruits, thereby protecting the fruits from oviposition. Bagging technique was reported as a successful control measure against the fruit fly for different types of cucurbits including bitter gourd, sponge gourd (Fang, 1982) and cucumber (Akhtaruzzaman et al., 1999). Therefore, the present study was undertaken to compare efficacy of different bagging materials for the control of the mango fruit fly.

The study was conducted at the mango orchards of Mango Research Station and Lac Research Station, Chapai Nawahganj during May to June 2001 and 2003 as these two years were on-year in respect of flowering, fruiting, and fruit harvest. The treatments were bagging of fruits with black polybag $\left(\mathrm{T}_{1}\right.$, bagging of fruits with transparent polybag $\left(T_{2}\right)$, bagging of fruits with brown paper bag $\left(T_{3}\right)$ and control (no bagging) $\left(\mathrm{T}_{4}\right)$. The most susceptible Langra and Khirshapat varieties were used in the study against the fruit fly. Randomly selected 50 fruits

${ }^{1}$ Entomology Division, BARI, Joydebpur, Gazipur-1701, ${ }^{2 \& 3}$ Lac Research Station, Kallyanpur, Chapai Nawabgonj-6300, Bangladesh. 
from each tree of each variety for each of the bagging treatments were bagged 30 days before crop harvest. In 1989, Karim reported that Bactrocera dorsalis prefer to lay eggs on mango fruits at 30 to 40 days before crop harvest. So, 30 days before crop harvest was selected as proper time of bagging for the protection of fruit fly infestation. Fifty randomly selected healthy fruits of each variety were also marked by tags for the unprotected control treatment in separate trees 30 days before crop harvest. At the time of crop harvest, harvested fruits of all treatments were checked for recording fruit fly infestation and physical fruit quality. After fruit harvest, 10 randomly selected fruits of each treatment including the untreated control were analyzed for recording percent total soluble solids (\% TSS) as the chemical fruit quality indicator.

Table 1. Efficacy of different bagging materials for the control of the mango fruit fly, Bactrocera dorsalis (Hendel) during mango season at Chapal Nawabgonj.

\begin{tabular}{l|l|l|c|c|c|c|c}
\hline Varieties & Treatments & \multicolumn{6}{c}{ Location(s) } \\
\cline { 3 - 8 } & & \multicolumn{3}{|c}{ Mango Research Station } & \multicolumn{3}{c}{ Lac Research Station } \\
\cline { 3 - 8 } & & $\begin{array}{c}\text { No. of } \\
\text { healthy } \\
\text { fruits }\end{array}$ & $\begin{array}{c}\text { No. of } \\
\text { infested } \\
\text { fruits }\end{array}$ & $\begin{array}{c}\% \text { fruit } \\
\text { infestation }\end{array}$ & $\begin{array}{c}\text { No. of } \\
\text { healthy } \\
\text { fruits }\end{array}$ & $\begin{array}{c}\text { No. of } \\
\text { infested } \\
\text { fruits }\end{array}$ & $\begin{array}{c}\text { \% fruit } \\
\text { infestation }\end{array}$ \\
\hline Langra & $\begin{array}{l}\text { Polybag } \\
\text { (black) }\end{array}$ & 50 & 0.0 & 0.0 & 50 & 0.0 & 0.0 \\
& $\begin{array}{l}\text { Polybag } \\
\text { (transparent) }\end{array}$ & 50 & 0.0 & 0.0 & 50 I & 0.0 & 0.0 \\
$\begin{array}{l}\text { Brown paper } \\
\text { bag }\end{array}$ & 50 & 0.0 & 0.0 & 50 & 0.0 & 0.0 \\
$\begin{array}{l}\text { Control (no } \\
\text { bagging) }\end{array}$ & 50 & 4.0 & 8.9 & 50 & 5.0 & 11.3 \\
\hline Khirshapat & $\begin{array}{l}\text { Polybag } \\
\text { (black) }\end{array}$ & 50 & 0.0 & 0.0 & 50 & 5.0 & 11.3 \\
$\begin{array}{l}\text { Polybag } \\
\text { (transparent) }\end{array}$ & 50 & 0.0 & 0.0 & 50 & 0.0 & 0.0 \\
$\begin{array}{l}\text { Brown paper } \\
\text { bag }\end{array}$ & 50 & 0.0 & 0.0 & 50 & 0.0 & 0.0 \\
$\begin{array}{l}\text { Control (no } \\
\text { bagging) }\end{array}$ & 50 & 4.5 & 9.8 & 50 & 6.5 & 14.2 \\
\hline
\end{tabular}

Data are the averages of the year 2001 and 2003.

Results in Table 1 showed that all three bagging materials gave full protection against the fruit fly infestation when unprotected fruits of the control treatment showed 8.9 to $14.2 \%$ fruit infestation. Protected fruits either by black or transparent polybag showed reduced \%TSS and increased level of physical 
Table 2. Effect of different bagging materials on percent total soluble solid (\%TSS) and other physical changes of mango fruits at crop harvest.

\begin{tabular}{|c|c|c|c|c|c|}
\hline \multirow[t]{3}{*}{ Varieties } & \multirow[t]{3}{*}{ Treatments } & \multicolumn{4}{|c|}{ Location(s) } \\
\hline & & \multicolumn{2}{|c|}{ Mango Research Station } & \multicolumn{2}{|c|}{ Lac Research Station } \\
\hline & & $\begin{array}{c}\text { \%TSS } \\
\text { (averages of } \\
10 \text { fruits) }\end{array}$ & $\begin{array}{c}\text { \% black } \\
\text { spots }\end{array}$ & $\begin{array}{c}\text { \%TSS } \\
\text { (averages of } \\
10 \text { fruits) }\end{array}$ & $\begin{array}{c}\text { \% black } \\
\text { spots }\end{array}$ \\
\hline \multirow[t]{4}{*}{ Langra } & Polybag(black) & 20.6 & 64.5 & 21.2 & 65.5 \\
\hline & $\begin{array}{l}\text { Polybag } \\
\text { (transparent) }\end{array}$ & 21.3 & 52.9 & 21.1 & 49.6 \\
\hline & $\begin{array}{l}\text { Brown paper } \\
\text { bag }\end{array}$ & 25.0 & 4.3 & 25.2 & 4.5 \\
\hline & $\begin{array}{l}\text { Control (no } \\
\text { bagging) }\end{array}$ & 25.3 & 7.8 & 25.9 & 5.6 \\
\hline \multirow[t]{4}{*}{ Khirshapat } & $\begin{array}{l}\text { Polybag } \\
\text { (black) }\end{array}$ & 19.3 & 51.6 & 20.1 & 44.5 \\
\hline & $\begin{array}{l}\text { Polybag } \\
\text { (transparent) }\end{array}$ & 19.7 & 45.7 & 19.9 & 43.3 \\
\hline & $\begin{array}{l}\text { Brown paper } \\
\text { bag }\end{array}$ & 24.6 & 5.5 & 24.2 & 4.1 \\
\hline & $\begin{array}{l}\text { Control (no } \\
\text { bagging) }\end{array}$ & 24.9 & 8.7 & 24.6 & 7.6 \\
\hline
\end{tabular}

fruit quality changes (\% black spots) in mango fruits bagged as compared with the above values of healthy fruits of the untreated control (Table 2). Bagging of fruits by the brown paper bag showed almost similar \% TSS (24.2 to 25.2\%) and better physical fruit quality (4.3 to 5.5\%) change as compared with those of the healthy fruits of the untreated control (24.6 to $25.9 \%$ TSS and 5.6 to $8.7 \%$ physical fruit quality change). In 1997, Hofman et al. reported that fruit mass, flesh colour, total soluble solids are not affected by white paper bag. Considering the fruit fly infestation, \% TSS and physical injury on mango fruits, among the three bagging teclmiques, bagging of mango fruits with brown paper bag in both the locations was effective for the control of mango fruit fly.

\section{References}

Akhtaruzzaman, M., M.Z. Alam and M.A. Sardar. 1999. Suppressing fruit fly infestation by bagging cucumber at different days after anthesis. Bangladesh. Entomol. 9 (1 \& 2): 103- 112.

Bhuyan, M.A.J., M.N. Uddin, M.G. Mortuza, M.S. Islam and B.C. Sarker. 2003. Catalogue on mango germplasm. Volume 1 (Indigenous Collection). Horticulture Research Centre. Bangladesh Agricultural Research Institute, Joydebpur, Gazipur and IPGRI-ADB-TFT Project Publ. 117p. 
Fang, M.N. 1982. A non-pesticide method for the control of melon fly. Special publication. Taichung District Agricultural Improvement Station, Taiwan. 16: 193205.

Hofman, P.J., L.G. Smith, D.C. Joyce, G.I. Johnson and G.F. Meiburg. 1997. Bagging of mango (Mangfera indica cv. Keitt) fruit influences fruit quality and mineral composition. Postharvest Biology and Technology 12(1) : 83-91.

Hossain, A.K.M.A. 1989. Manual on mango cultivation in Bangladesh. FAO/UNDP Publ. 82p.

Karim, M.A. 1989. Insect pest of mango. pp. 1-25. In : Hossain, A.K.M.A. (ed.). A field guide on insect pests and diseases of mango in Bangladesh and their control. FAO/UNDP Publ. 44p. 